УДК 334.722:364.46

\title{
ПРОБЛЕМИ СОЦІАЛЬНОГО ПІДПРИЕМНИЦТВА ПІД ЧАС ПАНДЕМІЇ
}

\section{PROBLEMS OF SOCIAL ENTREPRENEURSHIP DURING A PANDEMIC}

\author{
Фарат Олександра Володимирівна \\ доктор економічних наук, профресор, \\ Національний університет «Львівська політехніка» \\ ORCID: https://orcid.org/0000-0002-2192-4136 \\ Косовська Віра Василівна \\ кандидат економічних наук, старший викладач, \\ Національний університет «Львівська політехніка» \\ ORCID: https://orcid.org/0000-0001-6627-1856
Кедебец Крістіна Іштванівна
студент, \\ Національний університет «Львівська політехніка» \\ ORCID: https://orcid.org/0000-0003-1692-0373
}

\author{
Farat Oleksandra, Kosovska Vira, Kedebets Kristina \\ Lviv Polytechnic National University
}

\begin{abstract}
У статті охарактеризовано роль соціального підприємництва в Україні та світі як ефективного інструменту вирішення соціальних проблем як для громадянського суспільства, так і для малого та середнього бізнесу. Побудовано портрет соціального підприємця як людини, яка інтегрує виконання соціальної місії та бажання отримати прибуток від комерційної діяльності. Визначено сучасні проблеми соціального підприємництва в Україні. Охарактеризовано законодавство у сфері соціального підприємництва. Наведено приклади успішних соціальних підприємств, які змоги втримати свої позиції на ринку під час пандемії. Проаналізовано досвід зарубіжних країн щодо успішного розвитку соціального підприємництва та подолання наслідків спричинених COVID-19.

Ключові слова: малий та середній бізнес, соціальне підприємництво, проблеми розвитку, прибуток, економічне зростання, розвиток.
\end{abstract}

В статье охарактеризована роль социального предпринимательства в Украине и мире как эффективного инструмента решения социальных проблем как для гражданского общества, так и для малого и среднего бизнеса. Построен портрет социального предпринимателя как человека, который интегрирует выполнения социальной миссии и желание получить прибыль от коммерческой деятельности. Определены современные проблемы социального предпринимательства в Украине. Охарактеризованы законодательство в ссрере социального предпринимательства. Приведены примеры успешных социальных предприятий, которые смогли удержать своих позиции на рынке во время пандемии. Проанализирован опыт зарубежных стран по успешному развитию социального предпринимательства и преодоления последствий вызванных COVID-19.

Ключевые слова: малый и средний бизнес, социальное предпринимательство, проблемы развития, прибыль, экономический рост, развитие.

The article highlights the main problems of development of social entrepreneurship in Ukraine during a pandemic. Social entrepreneurship is characterised as a relatively young business tool that responds to social challenges through innovative concepts, creates additional social value and generates income for its own further development. Examples of successful social enterprises in Ukraine are given, which in their activities are based on market mechanisms, play important social roles in the society and use various organisational and legal forms. The Ukrainian realities as well as the experience of foreign countries in the activity of social enterprises has been characterised. The positive and negative sides of promoting its development are given. It is determined that in Ukraine the activity of social enterprises is not recognised in the legal field, which does not allow them to receive preferential treatment from the state for their social activities. Foreign models of social entrepreneurship are highlighted, which vary in the degree and forms of support they receive from the state. The 
impact of COVID-19 on social business in the world and in Ukraine is determined, in particular, it is determined that in the crisis period the existing social problems are exacerbated and there is a need for non-standard solutions. The activity of the Ukrainian Social Academy, which teaches entrepreneurs to start a social business, as well as free educational courses help to solve challenges that arise. In the conclusion it's determined, that the development of social entrepreneurship in Ukraine is a complex, large-scale, unpredictable process, especially during a pandemic. Therefore, state assistance in the form of giving preference to social entrepreneurs and active socio-economic policy in the form of socio-economic reforms will help to employ socially vulnerable groups, adapt them to modern living conditions and bring benefits to the state as a whole.

Keywords: small and medium business, social entrepreneurship, development problems, profit, economic growth, development.

Постановка проблеми. Останніми роками соціальне підприємництво перетворилося на дуже важливий та ефективний інструмент вирішення соціальних проблем, як для громадянського суспільства, такі для малого та середнього бізнесу нашої країни. Зростання актуальності цієї теми для України обумовлена, по-перше, реакцією суспільства на соціальні, економічні та політичні виклики, які пов'язані із російською військовою агресією проти України, та, по-друге, з процесом реформування країни в цілому. Тому визначення перспектив його розвитку та пошук шляхів вирішення проблеми слугують одним 3 основних напрямків активізації розвитку малого та середнього бізнесу в Україні.

Аналіз останніх досліджень і публікацій. Оскільки соціальне підприємництво $є$ поняттям доволі новим, то висвітлення проблем його розвитку розпочалося зовсім недавно. У 2017 році був виданий перший український підручник з соціального підприємництва «Соціальне підприємництво: від ідеї до суспільних змін». У формуванні даного підручника прийняв участь авторський колектив, який склали науковці, підприємці, представники сондів, громадські діячі, а саме: Корнецький Артем, Свинчук Анастасія, Назарук Василь, Гусак Наталія, Туманова Анастасія, Гончарова Марина. Проте, вже з 2018 року проблеми становлення та розвитку соціального підприємництва в Україні висвітлювалися багатьма авторами, серед них: Оксана Бойко, Юлія Клебан, Анна Гулевська-Черниш, Наталя Бордун, Діана Лапкіс та інші. У зарубіжних наукових працях проблеми розвитку соціального підприємництва досліджуються в роботах таких фрахівців, як В. Вайнер, М. Гульбекян, А. Керролл, М. Ван Марревійк, Я. Сандал, Ф. Спреклі та інші.

Мета статті $€$ висвітлення основних проблем розвитку соціального підприємництва в Україні в умовах пандемії.

Виклад основного матеріалу. Спалах COVID-19 на початку 2020 року, що перетворився на масштабну пандемію, та подальші карантинні обмеження суттєво вдарили майже по всіх сорерах бізнесу як в Україні, так і у світі. Значного негативного впливу зазнало і соціальне підприємництво.

Соціальне підприємництво - це відносно молодий інструмент бізнесу в Україні, який через інноваційні концепти реагує на соціальні виклики, створює додаткову соціальну цінність та, водночас, генерує дохід для свого подальшого розвитку. Соціальний бізнес виник на перетині благодійництва та традиційного бізнесу. Люди, які приходять в соціальний бізнес, мотивовані не лише заробітком, а також прагнуть допомогти вирішити певну суспільну проблему, а саме: захист навколишнього середовища, працевлаштування людей з особливими потребами, допомога потребуючим верствам населення тощо. Тому успіх такого підприємства дозволить вирішити певну соціальну потребу суспільства. При цьому наявність соціальної місії не виключає можливості отримання достойного прибутку.

Соціальні підприємці у своїй діяльності спираються на ринкові механізми, при цьому не випускаючи з поля зору свою основну соціальну місію, щоб врівноважувати моральні імперативи та прагнення прибутку та набувають різних організаційно-правових фрорм, а саме: Товариства з обмеженою відповідальністю (ТОВ), приватного підприємства (ПП), громадської організації (з комерційним проектом), благодійного соонду (з комерційним проектом), громадської організації + ФОП, громадської організація + ПП, кооперативу. В Україні фрункціонує близько 300 соціальних підприємств. Серед них: соціальне підприємство "WoodLuck", яка розробляє і виготовляє меблі з деревини та металу та працевлаштовує людей, які пройшли реабілітацію в центрах для алкозалежних і наркозалежних, допомагає їм з процесом ресоціалізації та адаптації; громадська організація "ЛедіДі Ательє", яке займається пошиттям хустинок різного формату та призначення та працевлаштовує людей, які перебували у важких життєвих ситуаціях, не зламались під випробуваннями долі і знайшли в собі сили рухатись до своєї мети; громадська організація "Центр "Жіночі перспективи", яка допомагає в працевлаштуванні осіб, що опинились в складних життєвих обставинах; 
студія дизайнерських рішень Zelenew, яка старі, нікому непотрібні пластмасові речі перетворює на нові, дизайнерські предмети інтер'єру; Львівська свічкова мануфактура, яка підтримує жінок з кризового центру, дає їм місце для праці у майстерні виготовленні свічок; громадська організація «Спільнота взаємодопомоги «Емаус-Оселя», яка допомагає безпритульним людям віднайти свою гідність у суспільстві та дає можливість реалізувати свої вміння у різноманітних видах діяльності та інші. Кожне з цих підприємств виконує важливу соціальну роль в житті суспільства в цілому, а соціальний підприємець, як агент суспільних змін, є піонером в області інновацій, який приносить користь людству. Соціальні підприємці амбітні, орієнтовані на місію й результати, стратегічні та винахідливі та досягають масштабних, систематичних і сталих соціальних змін через інновації, нестандартні підходи й ретельне застосування відомих технологій та стратегій. Тому користь від соціального підприємництва є неоціненна.

На жаль, в Україні діяльність соціальних підприємців $є$ нелегалізована, тобто не визнана у правовому полі, що не дозволяє отримувати від держави преференції від виконання соціальних фрункцій. До прикладу, зараз в Україні $€$ лише одна програма, яка кредитує соціальний бізнес, завдяки якій за 7 років проінвестовано лише 20 соціальних проєктів. Тому соціальні підприємства вимушені звертатися до міжнародних фрондів, де важко довести свій соціальний статус без підтвердження цього у власній країні. Незважаючи на те, що вже неодноразово були спроби прийняти Закон про соціальне підприємництво, усі вони не дійшли до свого логічного завершення. Тому головним завданням сьогодення $€$ надання соціальному підприємництву офріційного статусу та розроблення механізму його підтримки.

Єдиного успішного прикладу розвитку соціального підприємництва не існує. У багатьох країнах 3 потужною економікою теж відсутня законодавча підтримка соціального підприємства. Наприклад, у Великій Британії немає єдиного закону про соціальний бізнес. Проте, регулювання діяльності соціального підприємництва здійснюється в громадському секторі спеціальними асоціаціями, які надають бізнесу певні преференції у вигляді фрінансової та/або інсрормаційної допомоги при умові відповідності його певним критеріям.

Зарубіжні моделі соціального підприємництва відрізняються також і ступенем, і фрормами його підтримки з боку держави. Наприклад, модель Північної Європи (Бельгії, Нідерландів, Норвегії,
Швеції) характеризується активною підтримкою держави; моделі США, Канади, Японії містять регулювання на рівні підприємств, використання благодійництва; модель Центральної Європи (Австрії, Німеччини, Франції) відрізняється адресними соціальними програмами і бізнеспроектами [6]. Тому стає очевидним, що після легалізації соціального підприємництва у країні з'явиться додатковий помічник для вирішення соціальних проблем та допоможе впоратися 3 великим соціальним навантаженням. Це дозволить зменшити безробіття та соціальні виплати, надасть можливість адаптації певних категорій населення до сучасних умов життєдіяльності.

Подвійного удару соціальне підприємництво, як і практично весь малий бізнес, отримало від світової пандемії. Наприклад, у Бельгії активність соціальних підприємств знизилась більше, ніж наполовину, а 21\% бізнесів зовсім перестали працювати. А серед людей з інвалідністю, які були у штаті соціальних підприємств, залишилися працювати лише 16\%.

В Україні масштабні дослідження впливу COVID-19 на соціальний бізнес поки що не проводились. Однак, за даними Європейської Бізнес Асоціації, під час пандемії малий бізнес (до якого належить більшість соціальних підприємств) втратив від 50 до 75\% прибутку [3].

В кризовий час загострюються існуючі соціальні проблеми та виникає потреба у нестандартних рішеннях та соціальних інноваціях. В світовому масштабі 60 провідних організацій створили COVID Response Alliance for Social Entrepreneurs (Альянс реагування на COVID-19), головна мета якого - допомога соціальним підприємцям та боротьба 3 наслідками пандемії коронавірусу.

Незважаючи на недосконале законодавство, підтримати соціальних новаторів намагаються і в Україні. Наприклад, на програмах Української соціальної академії «Акселератор соціального підприємництва» та «Менеджмент соціальних інновацій» готують до запуску більше ніж 100 соціальних підприємств самої різноманітної спрямованості: від допомоги людям з інвалідністю до освітніх проєктів.

В кризу важливо зосередиться на аспектах, які важливі для виживання бізнесу. Необхідно об'єднувати зусилля для мінімізації негативних наслідків економічної кризи та недопущення закриття соціальних підприємств. Тому потреба соціальних підприємців у підтримці $€$ надзвичайно важливою. Цю роль взяла на себе Українська соціальна академія, яка навчає підприємців розпочати соціальний бізнес, а також за допомогою безкоштовних освітніх курсів і менторів 
допомагає підприємцям у вирішенні проблем, які виникають. В Українській соціальній академії розроблені програми з соціального підприємництва, на яких навчаються більше 100 соціальних підприємців. Також в академії провели безкоштовну онлайн-конфреренцію Social Navigator, де вчать соціальних підприємців адаптуватися до нових економічних реалій, допомагають розробити едрективну стратегію продажів та розвитку бізнесу. Основною ідеєю $€$ навчати не опускати руки, а боротися з тимчасовими труднощами. Отже, Українська соціальна академія намагається зробити все можливе, щоб підтримати соціальних підприємців у скрутні часи.

Висновки. Розвиток соціального підприємництва в Україні - процес складний, масштабний, непрогнозований, особливо в умовах пандемії. В умовах відсутності нормативнозаконодавчої бази та визнання статусу соціального підприємства, «вижити» даному бізнесу вкрай складно. Тому для активізації соціального підприємництва необхідно: проводити активне державне стимулювання з залученням різноманітних фоондів, надавати пресреренції в оподаткуванні та кредитуванні, здійснювати страхування ризиків, представляти інорормаційну підтримку, провадити роз'яснювальну політику серед населення країни про користь соціального підприємства, залучати ЗМІ, здійснювати просвітницьку діяльність у сфрері соціальних інновацій, залучати успішних соціальних підприємців в рамках обміну досвідом при вирішенні проблем, особливо під час пандемії. Дані заходи дозволять соціальним підприємцям провадити соціально-корисну діяльність, вирішувати екологічні проблеми, працевлаштовувати соціально-вразливі категорії населення, адаптуючи їх до сучасних умов життєдіяльності та принести корисний ефект суспільству в цілому.

\section{СПИСОК ВИКОРИСТАНИХ ДЖЕРЕЛ:}

1. Каменко Іван. Соціальне підприємництво яквідповідь суспільства на соціальні потреби. URL: https://biz.ligazakon. net/interview/205014_sotsalne-pdprimnitstvo-yak-vdpovd-susplstva-na-sotsaln-potrebi (дата звернення: 20.09.2021).

2. Корнецький Артем. Соціальне підприємництво: Ефрективний інструмент подолання соціальних викликів в Україні? URL: https://socialbusiness.in.ua/knowledge_base/sotsial-ne-pidpryiemnytstvo-efektyvnyy-instrumentpodolannia-sotsial-nykh-vyklykiv-v-ukraini (дата звернення: 20.09.2021).

3. Мельник Михайло. Соціальне підприємництво та COVID-19: як подолати кризу? URL: https://uww.prostir.ua/ ?library=sotsialne-pidpryjemnytstvo-ta-covid-19-yak-podolaty-kryzu (дата звернення: 20.09.2021).

4. Свинчук А.А., Корнецький А.О., Гончарова М.А., Назарук В.Я., Гусак Н.Є., Туманова А.А. Соціальне підприємництво: від ідеї до суспільних змін : посібник. Київ : ТОВ «ПІДПРИЄМСТВО «ВІ ЕН ЕЙ», 2017. 188 с.

5. Труднощі та перспективи соціального підприємництва - очима самих підприємців. URL: https://euprostir.org.ua/ stories/133500 (дата звернення: 24.09.2021).

6. Удодова В.І., Шаповал В.І. Дослідження досвіду фрункціонування національних моделей соціального підприємництва. Вісник Харківського національного університету ім. В.Н. Каразіна. 2013. № 1042. С. 105-108.

\section{REFERENCES:}

1. Kamenko Ivan. Sotsial'ne pidpryyemnytstvo yak vidpovid' suspil'stva na sotsial'ni potreby [Social entrepreneurship as a response of society to social needs]. Retrieved from: http:// biz.ligazakon.net/interview/205014_ sotsalne-pdprimnitstvo-yak-vdpovd-susplstva-na-sotsaln-potrebi (accessed 20 September 2021).

2. Kornets'kyy Artem. Sotsial'ne pidpryyemnytstvo: Efektyvnyy instrument podolannya sotsial'nykh vyklykiv v Ukrayini? [Social Entrepreneurship: An Effective Tool for Overcoming Social Challenges in Ukraine?]. Retrieved from: https://socialbusiness.in.ua/knowledge_base/sotsialne-pidpryiemnytstvo-efektyvnyy-instrument-podolanniasotsial-nykh-vyklykiv-v-ukraini (accessed 20 September 2021).

3. Mel'nyk Mykhaylo. Sotsial'ne pidpryyemnytstvo ta COVID-19: yak podolaty kryzu? [Social Entrepreneurship and COVID-19: how to overcome the crisis]. Retrieved from: http://www.prostir.ua/?library=sotsialne-pidpryjemnytstvo-ta-covid-19-yak-podolaty-kryzu (accessed 20 September 2021).

4. Svynchuk A.A., Kornets'kyy A.O., Honcharova M.A., Nazaruk V.Ya., Husak N.Ye., Tumanova A.A. (2017) Sotsial'ne pidpryyemnytstvo: vid ideyi do suspil'nykh zmin [Social entrepreneurship: from idea to social change]. Kyiv: VNA ENTERPRISE LLC.

5. Trudnoshchi ta perspektyvy sotsial'noho pidpryyemnytstva - ochyma samykh pidpryyemtsiv [Difficulties and prospects of social entrepreneurship - through the eyes of entrepreneurs themselves]. Retrieved from: https://euprostir.org.ua/stories/133500 (accessed 24 September 2021).

6. Udodova V.I., Shapoval V.I. (2013). Doslidzhennya dosvidu funktsionuvannya natsional'nykh modeley sotsial'noho pidpryyemnytstva. Visnyk Kharkivs'koho natsional'noho universytetu im. V.N. Karazina, 1042, 105-108. 